Article

\title{
Imaging Differential Mercury Species Bioaccumulation in Glass Eels Using Isotopic Tracers and Laser Ablation Inductively Coupled Plasma Mass Spectrometry
}

\author{
Mathilde Monperrus ${ }^{1, *}$, Christophe Pécheyran ${ }^{2}$ and Valérie Bolliet ${ }^{3}$ \\ 1 E2S UPPA, CNRS, IPREM, MIRA, UMR 5254, Université de Pau et des Pays de l'Adour, 64600 Anglet, France \\ 2 E2S UPPA, CNRS, IPREM, MIRA, UMR 5254, Université de Pau et des Pays de l'Adour, 64053 Pau, France; \\ christophe.pecheyran@univ-pau.fr \\ 3 E2S UPPA, INRAE, ECOBIOP, F64310, Université de Pau et des Pays de l'Adour, 64495 Saint-Pée-sur-Nivelle, \\ France; valerie.bolliet@univ-pau.fr \\ * Correspondence: mathilde.monperrus@univ-pau.fr
}

Received: 8 March 2020; Accepted: 31 March 2020; Published: 3 April 2020

check for updates

\begin{abstract}
Dramatic increases in global mercury pollution require a deeper understanding of specific toxicity mechanisms for mercury compounds in organisms. Despite numerous studies addressing mercury toxicity, the detailed mechanisms underlying its transport and accumulation in fish remain unclear. The aim of this study was to unravel differential uptake pathways for mercury compounds, metabolisation, and sequestration mechanisms in glass eels using techniques able to localize at the tissue and organ levels. A multi isotope image mapping procedure was developed to simultaneously study the uptake and distribution of both mercury compounds $\mathrm{MeHg}$ and $\mathrm{Hg}$ (II) within the organs of the whole organism. The use of isotopically labelled $\mathrm{Hg}$ species (methylmercury $\mathrm{Me}^{201} \mathrm{Hg}$ and inorganic mercury ${ }^{199} \mathrm{Hg}(\mathrm{II})$ ) and image based on isotope ratio instead of elemental signals allowed to visualize spatially and with time the differential $\mathrm{Hg}$ species uptake, transport, and sequestration routes. The results showed a preferential uptake of the $\mathrm{MeHg}$ counterpart and a dynamic transport of $\mathrm{MeHg}$ within different organs. The gills were the main target organs for MeHg uptake, whereas the skeletal muscle was the final $\mathrm{MeHg}$ storage tissue. $\mathrm{Hg}$ (II) was found to mainly transit by the gills and the olfactory bulbs with a very low transfer and storage in the other organs and a rapid depuration. No significant internal demethylation and methylation was observed during this experimentation.
\end{abstract}

Keywords: methylmercury; localization; uptake; organs; juvenile fish; laser ablation

\section{Introduction}

Mercury $(\mathrm{Hg})$ is recognized as a major pollutant and a hazardous metal for living organisms, owing to its toxicity, persistence, and bioaccumulation through the food web [1]. $\mathrm{Hg}$ is present under various chemical forms, which have different toxicities and health repercussions [2]. Hg compounds have long been recognized to target the central nervous system in vertebrates, particularly in developing or juvenile animals [3,4]. Inorganic mercury $(\mathrm{Hg}(\mathrm{II}))$ is generally less toxic than methylmercury (MeHg) and is able to cross the blood-brain barrier, causing irreversible damage to the nervous system, especially in the early stage of development [5]. Fish can take up $\mathrm{Hg}$ by absorbing it through the gills, but the primary source is the diet for most of them [6]. Previous works have shown that MeHg target different cells and tissues than $\mathrm{Hg}(\mathrm{II})$, with higher concentrations for $\mathrm{MeHg}$ in the eye lens epithelial cells and higher $\mathrm{Hg}(\mathrm{II})$ concentrations in the olfactory epithelium and the kidney [7,8]. MeHg usually dominates in the muscles of fish as $\mathrm{MeHg}$ is effectively assimilated and difficult to be depurated out 
the fish body compared with $\mathrm{Hg}$ (II) $[9,10]$. Despite its importance, relatively little is known about the mechanisms underlying the uptake, transport, and toxicity of different $\mathrm{Hg}$ species. The $\mathrm{Hg}$ toxicity in fish is not fully understood and more investigations on $\mathrm{Hg}$ species uptake and accumulation with respect to different organs at the whole animal level are needed to properly unravel specific impacts at the tissular and cellular level.

Analytical methods for the determination of $\mathrm{Hg}$ species in all organs are being developed and have to be improved as a prerequisite for studies on the uptake and the bioaccumulation processes of $\mathrm{Hg}$ species in organisms. For metals, the combination of laser ablation with element specific detection by laser ablation coupled to inductively coupled plasma mass spectrometry (LA-ICPMS) allows their determination, offering high sensitivity and high precision [11]. In addition, LA-ICPMS provides isotopic information, which is not the case for other imaging techniques. However, few studies report for imaging the coupling of LA-ICPMS with isotopic information [12]. The acquisition of isotope ratio images can provide relevant information in ecotoxicology studies; on one hand, isotopic ratios allow one to reveal isotopic fractionation processes within an organism and, on the other hand, the use of stable isotopic tracers permits one to visualize the uptake pathways and the circulation of the tagged element within the organism [11,13].

Acquiring a representative image of the localization of an element in an organism at any time represents a challenge to better understand the uptake and metabolic pathways of this element. The main objective of this work is to take advantage of the analytical capabilities of LA-ICPMS to image isotopic ratios within a whole organism to get a more understandable picture. LA-ICPMS parameters were set to acquire $\mathrm{Hg}$ isotope ratio images for longitudinal sections of European glass eels, which had been exposed to $\mathrm{Hg}$ species contamination with isotopically enriched $\mathrm{Me}^{201} \mathrm{Hg}$ and ${ }^{199} \mathrm{Hg}$ (II), as previously described in Claveau et al. [14]. The European eel (Anguilla anguilla L.) is considered as a specific bioindicator, by reflecting quite well the contamination of the surrounding environment [15]. This catadromous species spawns in the Sargasso Sea and the resulting larvae (Leptocephali) migrate northeast to coastal areas. Glass eels undergo a metamorphosis on the continental shelf before entering estuaries and migrate up for a developing phase into the yellow eel stage. The glass eel stage is transparent, which allows one to visualize the organs, and makes it an interesting model to test the LA-ICPMS method.

\section{Materials and Methods}

\subsection{Reagents}

Analytical reagent grade chemicals purchased from Sigma Aldrich (Saint Quentin, Fallavier, France) and water (18 M. $\mathrm{cm}$ ) obtained with a MilliQ system (Millipore Bedford, MA) were used throughout unless stated otherwise. Stock solutions $\left(1000 \mathrm{mg}(\mathrm{Hg}) \mathrm{L}^{-1}\right)$ of methylmercury of natural isotopic composition were prepared by dissolving methylmercury chloride (Strem Chemicals, USA) in methanol (Sigma Aldrich, France). Mercury standard solution of ${ }^{199} \mathrm{Hg}$ (II) $(91.7 \%)$ and $\mathrm{Me}^{201} \mathrm{Hg}$ (96.5\%) solution were purchased from ISC Science (Oveido, Spain). Standard solutions of ${ }^{199} \mathrm{Hg}(\mathrm{II})$ and $\mathrm{Me}^{201} \mathrm{Hg}\left(1000 \mathrm{mg} \mathrm{L}^{-1}\right)$ were prepared by dissolving mercury chloride in $1 \% \mathrm{HNO}_{3}$ and methylmercury chloride in methanol. Working standard solutions were prepared fresh daily by an appropriate dilution of stock standard solution in $1 \% \mathrm{HCl}$ and stored in the dark at $4{ }^{\circ} \mathrm{C}$. A $0.1 \mathrm{M}$ acetic acid-acetate buffer solution ( $\mathrm{pH}$ 4.7) $\left(\mathrm{CH}_{3} \mathrm{COONa}\right.$ : Merck Darmstadt, Germany; $\mathrm{CH}_{3} \mathrm{COOH}$ : Scharlau Extrapur) was prepared. A solution of $1 \%$ tetraethyl borate was prepared for ethylation reactions $(98 \%$, Stream Chemicals, Newburyport, USA). All reagents were of analytical grade. Ultrapure water was obtained from Milli-Q system (Quantum EX, Millipore, USA). Working standard solutions were prepared daily by an appropriate dilution of the stock standard solutions in water and stored at $4{ }^{\circ} \mathrm{C}$ until use. 


\subsection{Glass Eels Sampling and Conditioning}

Glass eels were captured using a net in April 2014 on the Atlantic coast, downstream from the mouth of the Huchet river (Moliets, South-Western France, $43^{\circ} 51$ N, $1^{\circ} 23 \mathrm{~W}$ ). After collection, glass eels were transferred to the laboratory and maintained at $11^{\circ} \mathrm{C}$ in a tank containing aerated water from the fishing site. Then, during one week, the water was continuously aerated and progressively diluted with commercial sping water before exposure.

\subsection{Exposure Conditions}

Two $10 \mathrm{~L}$ glass tanks were contaminated with isotopically enriched mercury species $\left({ }^{201} \mathrm{MeHg}\right.$, ${ }^{199} \mathrm{Hg}(\mathrm{II})$ ) added to commercial spring water at a concentration of $100 \mathrm{ng} \mathrm{L}^{-1}$. The tanks were kept for 15 days in the same room at $11 \pm 0.5^{\circ} \mathrm{C}$, with a photoperiod $12 \mathrm{~L} / 12 \mathrm{D}$ and $\operatorname{dim} \operatorname{light}\left(2.92 \times 10^{-3} \mu \mathrm{W} . \mathrm{cm}^{-1}\right)$ during the photophase. $\mathrm{pH}$ and oxygen concentrations were measured daily in the tank. Water was not bubbling in order to prevent adsorption of mercury compounds on tubing. When water oxygen concentration declined under $80 \%$ saturation, the water was aerated using a small polypropylene tube until 100\% saturation was attained. Then, 14 glass eels were introduced in each tank. Four glass eels per tank were removed after 8 h, 7 days, and 15 days of exposure. All glass eels were anesthetized in the water of their tank, rinsed in freshwater to remove all traces of pollutant that could remain on the surface, and individually measured for wet weight (Sartorius CP 153 balance, $\pm 1.0 \mathrm{mg}$ ) and length $( \pm 1.0 \mathrm{~mm})$ before freezing at $-20^{\circ} \mathrm{C}$. For each kinetic time, a total of eight glass eels were sampled, with four glass eels dedicated to gas chromatography-inductively coupled plasma mass spectrometry (GC-ICPMS) analysis and four to LA-ICPMS analysis.

\subsection{Mercury Speciation Analysis}

Mercury species concentrations were determined in four non-contaminated glass eels, four contaminated and exposed during 1 day, four contaminated and exposed during 7 days, and four contaminated and exposed during 15 days. After sampling, each glass eel was freeze-dried and powdered using an agate mortar. Each individual was then extracted under microwave radiations according the procedure previously described by Navarro et al. [16]. The supernatant was then spiked with known amounts of standard solutions of $\mathrm{MeHg}$ and $\mathrm{Hg}$ (II) of natural isotopic composition and submitted to ethylation. Mercury speciation analysis was performed by GC-ICPMS using the method with parameters detailed by Navarro et al. [16]. Both endogenous (naturally assimilated) and exogenous (derived from the spiked $\mathrm{Me}^{201} \mathrm{Hg}$ and ${ }^{199} \mathrm{Hg}(\mathrm{II})$ ) mercury species were quantified by the isotopic pattern deconvolution methodology [17].

\subsection{Sample Preparation for LA-ICPMS}

Glass eels were plunged in Tissue Freezing Medium ${ }^{\circledR}$ (Jung, Leica, Germany) to embed and maintain the glass eel during slicing without penetration of the medium into tissues. The glass eels were then promptly solidified in liquid nitrogen and cut off in $50 \mu \mathrm{m}$ thick slices using a Leica CM3050 cryomicrotome. The first five slices were unused. The following slices were then deposited in custom PMMA (poly(methyl methacrylate)) slides (40 $\mathrm{mm} \times 20 \mathrm{~mm} \times 2 \mathrm{~mm}$ ), without any adhering medium. Samples were dried at room temperature and then kept in closed Petri dishes in the dark before LA-ICPMS analysis. For each sample, a picture using a microscope allow to identify the different organs.

\subsection{Laser Ablation ICPMS}

A high repetition rate femtosecond laser (Alfamet, Nexeya France) was coupled to a quadrupole ICPMS (DRC2, Perkin Elmer) for analyzing glass eel slices. This laser allowed combining a high repetition rate with the fast movement of a small laser beam (10 microns) driven by galvanometric scanners in order to create a virtual beam shaping. A rectangular $10 \times 50$ microns spot was then 
simulated by rapidly moving the $10 \mu \mathrm{m}$ laser beam according to a $50 \mu \mathrm{m}$ back and forth movement of the laser beam at a speed of $2 \mathrm{~ms}^{-1}$ and a repetition rate of $300 \mathrm{~Hz}$. Images were built from the fsLA/ICPMS signal resulting from the samples ablation according to a series of vertically distributed horizontal lines. Taking into account that the washout time of the laser cell was about $0.5 \mathrm{~s}$ and the ICPMS was set to acquire one point per second, the sample translation was set to $50 \mu \mathrm{ms}^{-1}$ and the space between lines was set to $50 \mu \mathrm{m}$ in order to obtain square pixels of $50 \times 50 \mu \mathrm{m}$. In other words, the image resolution was set to $50 \mu \mathrm{m}$. In these conditions, the signal was acquired from $3 \mathrm{~h}$ to $7 \mathrm{~h}$ depending on the sample size $(9 \times 3 \mathrm{~mm}$ to $17 \times 3.6 \mathrm{~mm}$, respectively). A complete description of this fsLA/ICPMS coupling can be found elsewhere $[18,19]$.

The laser parameters (spot size, repetition rate, energy, laser beam movement, and sample advancement speed) were carefully adjusted in order to insure the complete ablation of the eel slices while preventing excessive ablation of the PMMA slides. Excessive ablation of the PPMA slides would otherwise affect the ICPMS robustness and eventually increase the mercury isotope background. Laser and ICPMS parameters are presented in Table 1.

Table 1. Instrumental operating conditions used for glass eel slices laser ablation coupled to inductively coupled plasma mass spectrometry (LA-ICPMS) imaging.

\begin{tabular}{|c|c|}
\hline \multicolumn{2}{|c|}{ Laser Ablation Conditions } \\
\hline Laser Ablation System & $\begin{array}{c}\text { ALFAMET (Nexeya) fitted with an HP1 fs } \\
\text { laser source (Amplitude Système) }\end{array}$ \\
\hline Wavelength & $1030 \mathrm{~nm}$ \\
\hline Pulse duration & $400 \mathrm{fs}$ \\
\hline Repetition rate & $300 \mathrm{~Hz}$ \\
\hline Energy & $3 \mu \mathrm{J}$ \\
\hline Spot diameter (Airy $1 / \mathrm{e}^{2}$ ) & $10 \mu \mathrm{m}$ \\
\hline Scan speed (y axis) & $2 \mathrm{~mm} \mathrm{~s}^{-1}$ \\
\hline Stage speed ( $\mathrm{x}$ axis) & $50 \mu \mathrm{m} \mathrm{s}^{-1}$ \\
\hline Space between lines & $50 \mu \mathrm{m}$ \\
\hline Transport gas & $\mathrm{He}, 1 \mathrm{~L} \mathrm{~min}^{-1}$ \\
\hline \multicolumn{2}{|c|}{ ICPMS: DRC2, Perkin Elmer } \\
\hline RF power & $1200 \mathrm{~W}$ \\
\hline Ar plasma/auxiliary flow rates & 15.0/0.9 $\mathrm{L} \mathrm{min}^{-1}$ \\
\hline Dwell time per acquisition point & $100 \mathrm{~ms}$ \\
\hline Number of sweeps & 100 \\
\hline Isotopes monitored & ${ }^{198} \mathrm{Hg}^{+},{ }^{199} \mathrm{Hg}^{+},{ }^{200} \mathrm{Hg}^{+},{ }^{201} \mathrm{Hg}^{+},{ }^{202} \mathrm{Hg}^{+}$ \\
\hline
\end{tabular}

\subsection{Data Handling Treatment}

Raw signals were processed using a laboratory-made fit for purpose software (FOCAL). This series of VBA macros works in Excel environment. It allows the matrix image construction, background subtraction (based on the gas black prior to ablation), and isotope ratio calculation. No mass bias correction was applied as the isotope ratios variations measured here were high enough (exceeding a factor three, see below) to make any mass bias correction useless for the scope of the paper. The matrix images were then exported in csv format to be processed with ImageJ software.

\section{Results and Discussion}

\subsection{Endogenous Hg Concentration and Localization}

The mean weight and length of glass eels were $240 \pm 30 \mathrm{mg}$ and $67 \pm 1 \mathrm{~mm}$, respectively. Naturally assimilated mercury species concentrations were $143.4 \pm 5.8$ and $20.6 \pm 1.3 \mathrm{ng} / \mathrm{g} \mathrm{dw}$ for $\mathrm{MeHg}$ and $\mathrm{Hg}(\mathrm{II})$, respectively $(\mathrm{n}=12)$, which is in accordance with a previous study [14].Figure 1 presents the qualitative distribution of endogenous ${ }^{200} \mathrm{Hg}$ in a $50 \mu \mathrm{m}$ thick section of a glass eel specimen. This figure 
allocates the body parts where the $\mathrm{Hg}$ preferably bioaccumulates. Two regions visibly accumulate $\mathrm{Hg}$; that is, the muscle and the heart. Although less clear, the outer layer of the eye also seems to present bioaccumulation. However, from this image, it is impossible to determine the uptake way of the $\mathrm{Hg}$ incorporated in the glass eel, nor the chemical form of $\mathrm{Hg}$ stored in the organisms ( $\mathrm{MeHg} / \mathrm{Hg}$ (II)) or their redistribution. Moreover, the different tissues have different densities, which may influence the ablation rates. The image of $\mathrm{Hg}$ distribution is certainly biased by the ablation rate for the different body parts and can not represent an accurate quantitative $\mathrm{Hg}$ distribution.

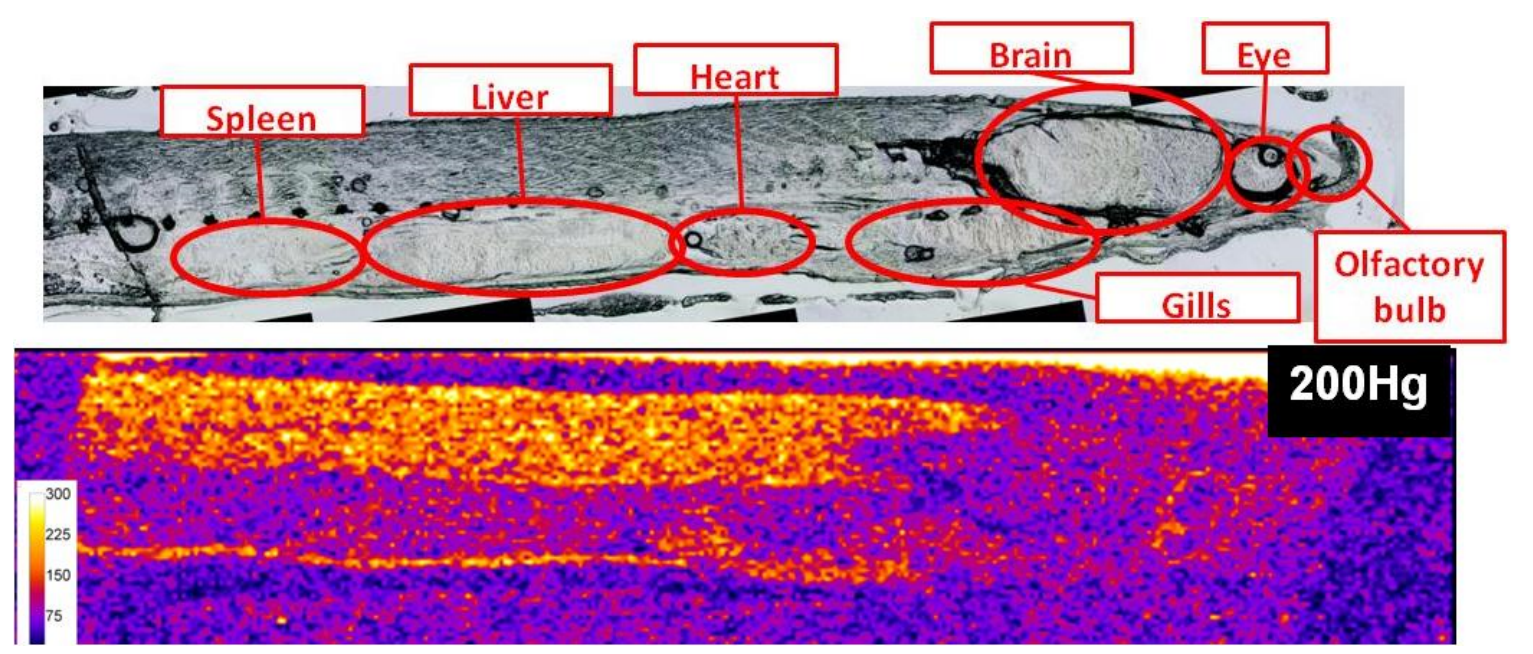

Figure 1. Qualitative distribution of endogeneous ${ }^{200} \mathrm{Hg}$ in a $50 \mu \mathrm{m}$ thick section of a glass eel specimen (scale represents ${ }^{200} \mathrm{Hg}$ signal intensity in counts per second).

\section{2. $\mathrm{Me}{ }^{201} \mathrm{Hg}$ and ${ }^{199} \mathrm{Hg}(\mathrm{II})$ Concentrations}

Bioaccumulation in glass eels under $\mathrm{Me}^{201} \mathrm{Hg}$ and ${ }^{199} \mathrm{Hg}$ (II) exposure $\left(100 \mathrm{ng} . \mathrm{L}^{-1}\right)$ with time is presented in Figure 2. After seven days of $\mathrm{Hg}$ species exposure followed by eight days in commercial water without contaminant, glass eels reached exogenous $\mathrm{Me}^{201} \mathrm{Hg}$ concentrations at 10 times higher than ${ }^{199} \mathrm{Hg}$ (II) ones with $139.6 \pm 16.2$ and $14.8 \pm 2.3 \mathrm{ng} / \mathrm{g} \mathrm{dw}$, respectively. These results confirm a preferential uptake of $\mathrm{MeHg}$, as previously documented for invertebrates [20,21] and fish [9,10]. Indeed, $\mathrm{MeHg}$ is well-known to readily go across biological membranes and to exhibit a higher uptake efficiency than $\mathrm{Hg}$ (II) [22]. In addition, $\mathrm{MeHg}$ and more precisely the $\mathrm{MeHg}$ - thiols compounds complexes have a high level of similarity with endogenous substrates for the active transporters that regulate the cellular uptake and efflux of molecules into the cells, and thus promote its higher accumulation in tissues [8]. Finally, very low concentrations of ${ }^{201} \mathrm{Hg}(\mathrm{II})$ (deriving from $\mathrm{Me}^{201} \mathrm{Hg}$ ) and $\mathrm{Me}^{199} \mathrm{Hg}$ (deriving from ${ }^{199} \mathrm{Hg}(\mathrm{II})$ ) were measured in glass eels, demonstrating the low transformation potentials for $\mathrm{Me}^{201} \mathrm{Hg}$ to demethylate and ${ }^{199} \mathrm{Hg}$ (II) to methylate. 


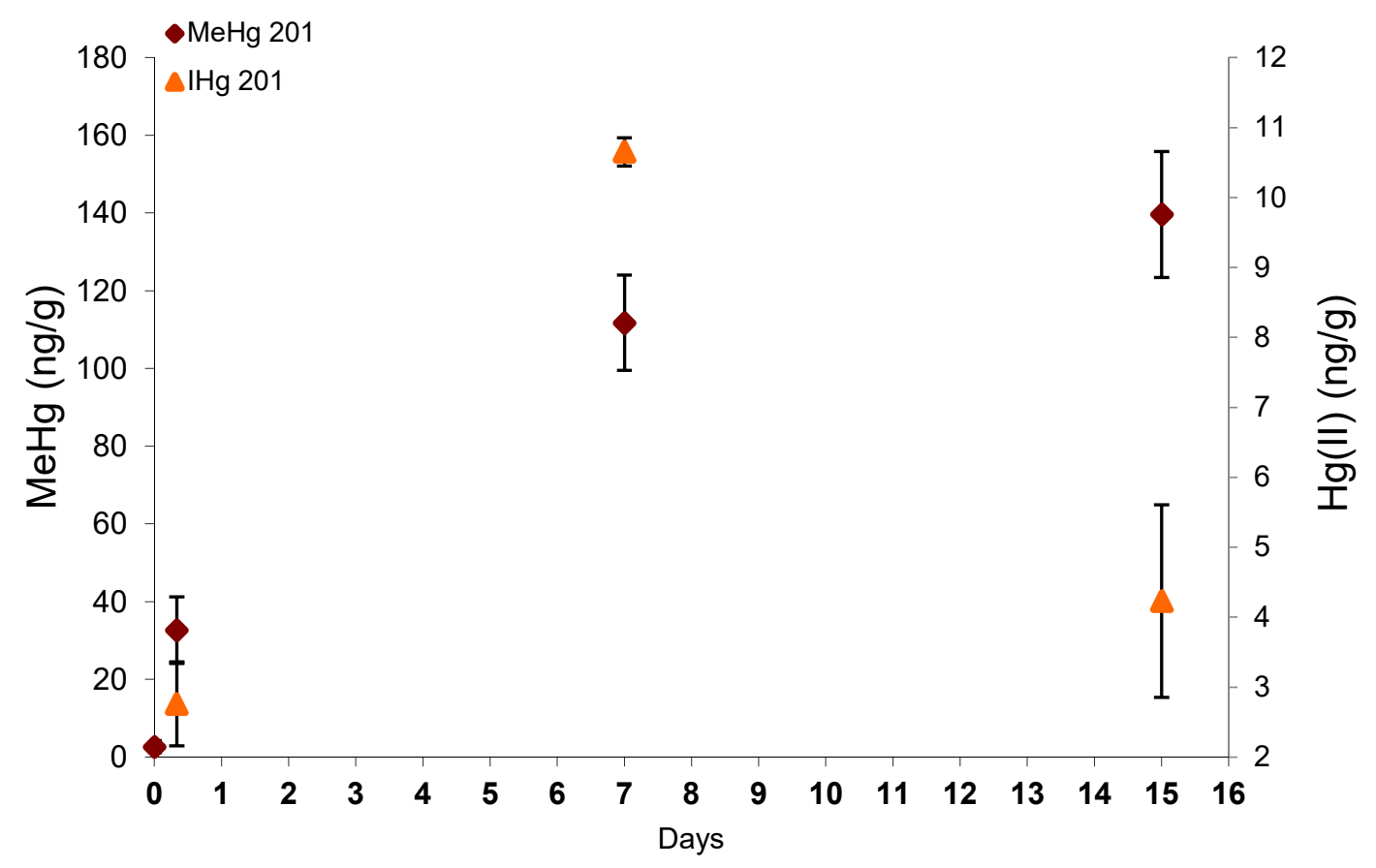

(A)

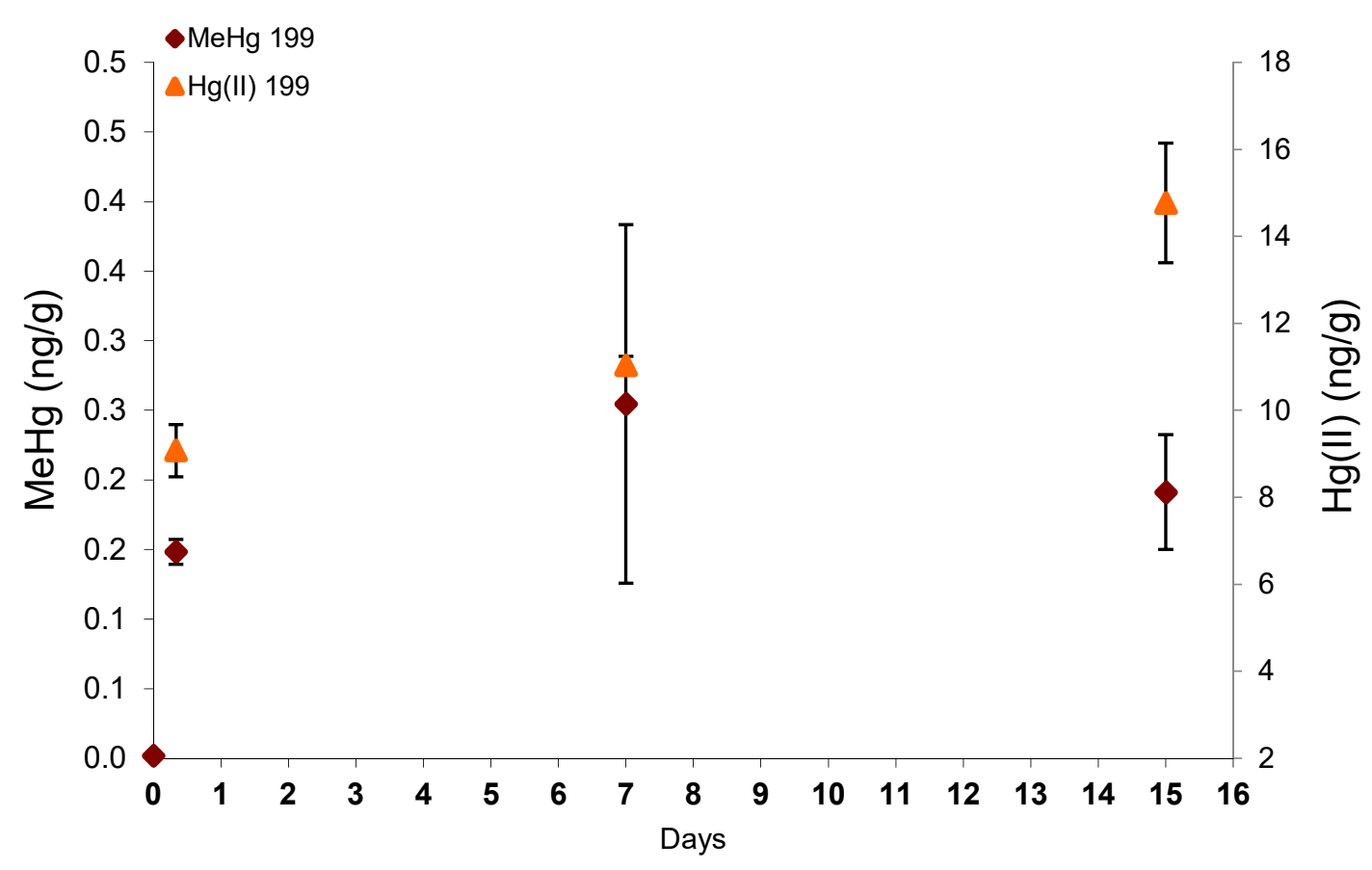

(B)

Figure 2. Exogenous mercury species concentrations derived from the spiked $\mathrm{Me}^{201} \mathrm{Hg}(\mathbf{A})$ and ${ }^{199} \mathrm{Hg}$ (II) (B) with time. 


\subsection{Hg Species Localization and Redistribution}

Unlike the simple image of the distribution of the mercury element, the use of two isotopically enriched tracers specific to each mercury species $\left({ }^{201} \mathrm{MeHg},{ }^{199} \mathrm{Hg}\right.$ (II)) makes it possible to produce images of the isotopic ratios 200/201 and 200/199 more accurately and specifically representing the behavior of each mercury species with time.

The elemental signals were transformed into isotopic ratios according the procedure described in Section 2.5. Figure 3 shows the isotope ratio images for ratio 200/201, referring to the presence of $\mathrm{MeHg}$, and ratio 200/199, referring to the presence of $\mathrm{Hg}(\mathrm{II})$, after $8 \mathrm{~h}, 7$ days, and 15 days of the experiment. Isotopic ratios 200/201 and 200/199 were lower than 1.75 and 1.37 for the natural isotopic ratios, respectively, indicating an important enrichment in isotopes 201 and 199 coming from the $\mathrm{Me}^{201} \mathrm{Hg}$ and $\left.{ }^{199} \mathrm{Hg}(\mathrm{II})\right)$ added, respectively. The results showed that $\mathrm{Hg}$ accumulation fingerprintings vary remarkably with the chemical form of mercury. As previously observed in zebrafish, $\mathrm{MeHg}$ targeted different organs than $\mathrm{Hg}$ (II), indicating the importance of chemical speciation on the target cells and tissues for $\mathrm{Hg}$ accumulation [8].

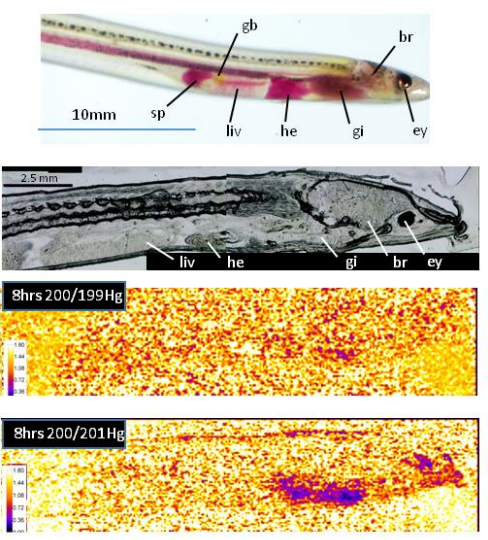

(a)

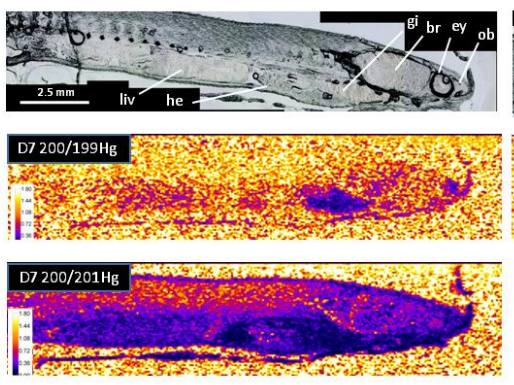

(b)

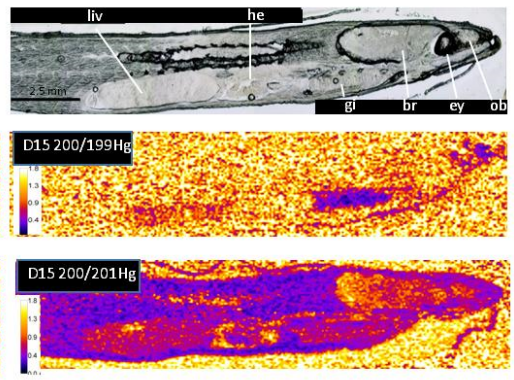

(c)

Figure 3. Isotope ratio images for ratio 200/201, referring to the presence of $\mathrm{MeHg}$, and ratio 200/199, referring to the presence of $\mathrm{Hg}(\mathrm{II})$, after $8 \mathrm{~h}$ (a), 7 days (b), and 15 days (c) of the experiment (br: brain, ey: eye, gb: gall bladder, gi: gills, he: heart, liv: liver, ob: olfactory bulb, sp: spleen).

After eight hours' exposure, the isotopic ratio 200/199 did not show any enrichment in isotope 199, indicating no accumulation of $\mathrm{Hg}$ (II) in glass eels (Figure 3a). After seven days, $\mathrm{Hg}$ (II) was mainly observed in the gills and the olfactory bulbs, while a very low bioaccumulation was detected in the liver, the heart, and the brain (Figure $3 b$ ). Then, following one week in freshwater, bioaccumulation persisted in the gills, but decreased or almost disappeared in the others organs, suggesting depuration processes (Figure 3c). These results show that the main uptake way for $\mathrm{Hg}$ (II) in glass eels was through the gills. In the literature, dietary exposure has been considered as the major route of mercury uptake in fish [6], but in starving glass eels maintained in freshwater, a primary uptake through the gills is not surprising. Indeed, in contrast to marine glass eels, freshwater individuals do not have to drink to maintain their osmolarity and gills are directly exposed to water, representing a relevant interface with $\mathrm{Hg}$ (II). The $\mathrm{Hg}$ (II) way into the gills might also be made possible owing to the enhancement of the physiological gradient as a result of the counter-current principle between the flows of water and blood outside and inside the gill structures [23]. Our results also showed that a second target for $\mathrm{Hg}$ (II) in glass eels was an area that may correspond to the olfactory bulbs. Such an observation is consistent with previous studies conducted in larval-stage zebrafish, showing that $\mathrm{Hg}$ (II) can specifically target the olfactory epithelium $[8,24]$.

As observed for $\mathrm{Hg}(\mathrm{II})$, the main uptake way for $\mathrm{Me}^{201} \mathrm{Hg}$ after eight hours' exposure in starving glass eels was the gills (Figure 3a). The skin also contained $\mathrm{Me}^{201} \mathrm{Hg}$ at lower levels, which allows 
to recognized the shape of the organism. After seven days' exposure (Figure 3b), the highest bioaccumulation of MeHg was observed in the gills and the heart, followed by the liver and the spleen. The brain showed lower values, but the lowest accumulation was observed in the muscle. Then, one week after exposure, a redistribution was observed, with the highest bioaccumulation in the muscle (Figure 3c). The heart ventricle maintained accumulation, while it decreased in the viscera and the gills. No accumulation was observed in the eye, in contrast to that observed for the endogenous ${ }^{200} \mathrm{Hg}$ (Figure 2). These results show a dynamic transport of $\mathrm{MeHg}$ within different organs. After rapid uptake through the gills, MeHg was transported in the heart, the liver, and the brain, and finally transferred to the muscle. According to the literature, dietary $\mathrm{MeHg}$ would be delivered to the liver through a portal system after uptake in the intestine [22,25]. Then, $\mathrm{MeHg}$ could cross the hepatocyte plasma membrane and bind to thiol groups before being eliminated by the bile or redistributed by blood stream to other target tissues as muscles [26,27]. When taken up by the gills, MeHg may first be transported to the heart and then to the liver before being redistributed to other organs or tissues. MeHg determination in the skeletal muscle is consistent with the results obtained for the endogenous ${ }^{200} \mathrm{Hg}$, confirming that mercury mainly bioaccumulates under the methyl form. This is also in accordance with a previous analysis on numerous species collected in natural freshwater or marine systems [26]. The higher accumulation of $\mathrm{MeHg}$ than $\mathrm{Hg}$ (II) observed in the brain of glass eels has also been reported in other species $[3,8,28]$. The brain is protected by the blood-brain barriers, which strictly regulate the transport of molecules from the bloodstream. However, in contrast to $\mathrm{Hg}(\mathrm{II})$, thiol-bound $\mathrm{MeHg}$ (specifically $\mathrm{MeHg}$ cysteineate, the most dominant form of $\mathrm{MeHg}$ in vivo) can penetrate these barriers.

\subsection{Implications for Future}

A tracer experiment using different enriched stable isotopes enriched mercury species and followed by isotope ratio imaging by LA-ICPMS was designed to make possible the visualization of differential uptake routes of each mercury species. This approach allowed to quantitatively determine the tissues where $\mathrm{Hg}$ species are accumulated and transferred with time. This promising methodology allows obtaining further spatial and kinetic information on the element/species under consideration, enabling the interpretation of element/species uptake, transport, and sequestration routes. This method is equally applicable to the study of other elements of concern. Coupling other isotopically labelled elemental species such as selenium species, which are known to play an important role for $\mathrm{Hg}$ species bioaccumulation, is also possible. Simultaneous dynamic imaging of both $\mathrm{Hg}$ and Se species would help to understand their synergetic effects.

Author Contributions: Conceptualization, M.M. and V.B.; Data curation, M.M. and C.P.; Formal analysis, M.M., C.P. and V.B.; Methodology, M.M., C.P. and V.B.; Writing - original draft, M.M. and V.B.; Writing - review \& editing, C.P. All authors have read and agreed to the published version of the manuscript.

Funding: This research received no external funding.

Acknowledgments: We wish to thank the IE ECP and Pascale Coste, Emmanuel Huchet, and Jacques Rives for their technical assistance.

Conflicts of Interest: The authors declare no conflict of interest.

\section{References}

1. Beckers, F.; Rinklebe, J. Cycling of mercury in the environment: Sources, fate, and human health implications: A review. Crit. Rev. Environ. Sci. Technol. 2017, 47, 693-794. [CrossRef]

2. Bridges, C.C.; Zalups, R.K. Mechanisms involved in the transport of mercuric ions in target tissues. Arch. Toxicol. 2016, 91, 63-81. [CrossRef] [PubMed]

3. Ribeiro, C.A.D.O.; Belger, L.; Pelletier, E.; Rouleau, C. Histopathological evidence of inorganic mercury and methyl mercury toxicity in the arctic charr (Salvelinus alpinus). Environ. Res. 2002, 90, 217-225. [CrossRef]

4. Gentès, S.; Monperrus, M.; Legeay, A.; Maury-Brachet, R.; Davail, S.; André, J.-M.; Guyoneaud, R. Incidence of invasive macrophytes on methylmercury budget in temperate lakes: Central role of bacterial periphytic communities. Environ. Pollut. 2013, 172, 116-123. [CrossRef] [PubMed] 
5. Maulvault, A.; Custodio, A.; Anacleto, P.; Repolho, T.; Pousão, P.; Nunes, M.; Diniz, M.; Rosa, R.; Marques, A. Bioaccumulation and elimination of mercury in juvenile seabass (Dicentrarchus labrax) in a warmer environment. Environ. Res. 2016, 149, 77-85. [CrossRef] [PubMed]

6. Ribeiro, C.A.D.O.; Rouleau, C.; Pelletier, E.; Audet, C.; Tjälve, H. Distribution Kinetics of Dietary Methylmercury in the Arctic Charr (Salvelinus alpinus). Environ. Sci. Technol. 1999, 33, 902-907. [CrossRef]

7. Korbas, M.; Krone, P.H.; Pickering, I.J.; George, G.N. Dynamic accumulation and redistribution of methylmercury in the lens of developing zebrafish embryos and larvae. JBIC J. Boil. Inorg. Chem. 2010, 15, 1137-1145. [CrossRef]

8. Korbas, M.; Macdonald, T.C.; Pickering, I.J.; George, G.N.; Krone, P.H. Chemical Form Matters: Differential Accumulation of Mercury Following Inorganic and Organic Mercury Exposures in Zebrafish Larvae. ACS Chem. Boil. 2011, 7, 411-420. [CrossRef]

9. Polak-Juszczak, L. Distribution of organic and inorganic mercury in the tissues and organs of fish from the southern Baltic Sea. Environ. Sci. Pollut. Res. 2018, 25, 34181-34189. [CrossRef]

10. Peng, X.; Liu, F.; Wang, W.-X. Organ-specific accumulation, transportation and elimination of methylmercury and inorganic mercury in a low $\mathrm{Hg}$ accumulating fish. Environ. Toxicol. Chem. 2016, 35, 2074-2083. [CrossRef]

11. Becker, J.S.; Matusch, A.; Wu, B. Bioimaging mass spectrometry of trace elements - recent advance and applications of LA-ICP-MS: A review. Anal. Chim. Acta 2014, 835, 1-18. [CrossRef] [PubMed]

12. Flórez, M.R.; Aramendía, M.; Resano, M.; Lapeña, A.C.; Balcaen, L.; Vanhaecke, F. Isotope ratio mapping by means of laser ablation-single collector-ICP-mass spectrometry: Zn tracer studies in thin sections of Daphnia magna. J. Anal. At. Spectrom. 2013, 28, 1005-1015. [CrossRef]

13. Lobo, L.; Pereiro, R.; Fernández, B. Opportunities and challenges of isotopic analysis by laser ablation ICP-MS in biological studies. TrAC Trends Anal. Chem. 2018, 105, 380-390. [CrossRef]

14. Claveau, J.; Monperrus, M.; Jarry, M.; Baudrimont, M.; Gonzalez, P.; Cavalheiro, J.; Mesmer-Dudons, N.; Bolliet, V. Methylmercury effects on migratory behaviour in glass eels (Anguilla anguilla): An experimental study using isotopic tracers. Comp. Biochem. Physiol. Part C Toxicol. Pharmacol. 2015, 171, 15-27. [CrossRef]

15. Arleny, I.; Tabouret, H.; González, O.C.; Bareille, G.; Donard, O.F.; Amouroux, D. Methylmercury bioconcentration in muscle tissue of the European eel (Anguilla anguilla) from the Adour estuary (Bay of Biscay, France). Mar. Pollut. Bull. 2007, 54, 1031-1036. [CrossRef]

16. Navarro, P.; Clémens, S.; Perrot, V.; Bolliet, V.; Tabouret, H.; Guérin, T.; Amouroux, D. Simultaneous determination of mercury and butyltin species using a multiple species-specific isotope dilution methodology on the European, Anguilla anguilla glass eel and yellow eel. Int. J. Environ. Anal. Chem. 2013, 93, 166-182. [CrossRef]

17. González, O.C.; Bouchet, S.; Monperrus, M.; Tessier, E.; Amouroux, D. In situ experiments for element species-specific environmental reactivity of tin and mercury compounds using isotopic tracers and multiple linear regression. Environ. Sci. Pollut. Res. 2012, 20, 1269-1280. [CrossRef]

18. Claverie, F.; Fernández, B.; Pécheyran, C.; Alexis, J.; Donard, O.F.X. Elemental fractionation effects in high repetition rate IR femtosecond laser ablation ICP-MS analysis of glasses. J. Anal. At. Spectrom. 2009, 24, 891-902. [CrossRef]

19. Tabouret, H.; Bareille, G.; Claverie, F.; Pécheyran, C.; Prouzet, P.; Donard, O.F. Simultaneous use of strontium:calcium and barium:calcium ratios in otoliths as markers of habitat: Application to the European eel (Anguilla anguilla) in the Adour basin, South West France. Mar. Environ. Res. 2010, 70, 35-45. [CrossRef]

20. Tsui, M.T.K.; Wang, W.-X. Uptake and Elimination Routes of Inorganic Mercury and Methylmercury inDaphnia magna. Environ. Sci. Technol. 2004, 38, 808-816. [CrossRef]

21. Lopes, C.; Vale, C.; Canário, J.; Branco, V.; Moura, I. Relations between mercury, methyl-mercury and selenium in tissues of Octopus vulgaris from the Portuguese Coast. Environ. Pollut. 2010, 158, 2094-2100.

22. Bridges, C.C.; Zalups, R.K. Transport of inorganic mercury and methylmercury in target tissues and organs. J. Toxicol. Environ. Health Part B 2010, 13, 385-410. [CrossRef] [PubMed]

23. Pereira, P.; Lopes, C.; Barata, M.; Araújo, O.; Canário, J.; Almeida, A.; Pacheco, M.; Pousão-Ferreira, P. A new page on the road book of inorganic mercury in fish body-Tissue distribution and elimination following waterborne exposure and post-exposure periods. Metallomics 2015, 7, 525-535. [CrossRef] [PubMed]

24. Macdonald, T.; Sylvain, N.J.; James, A.K.; Pickering, I.J.; Krone, P.H.; George, G.N. Effects of Inorganic Mercury on the Olfactory Pits of Zebrafish Larvae. Metallomics 2016, 8, 514-517. [CrossRef] [PubMed] 
25. Mela, M.; Neto, F.F.; Yamamoto, F.; Almeida, R.D.A.D.; Grötzner, S.R.; Ventura, D.; Ribeiro, C.A.D.O. Mercury distribution in target organs and biochemical responses after subchronic and trophic exposure to Neotropical fish Hoplias malabaricus. Fish Physiol. Biochem. 2013, 40, 245-256. [CrossRef]

26. Harris, H.H. The Chemical Form of Mercury in Fish. Science 2003, 301, 1203. [CrossRef]

27. Ribeyre, F.; Boudou, A. Etude expérimentale des processus de décontamination chez Salmo gairdneri, après contamination par voie directe avec deux dérivés du mercure $\left(\mathrm{HgCl}_{2}\right.$ et $\left.\mathrm{CH}_{3} \mathrm{HgCl}\right)$-Analyse des transferts aux niveaux 'organisme' et 'organes'. Environ. Pollut. Ser. A Ecol. Boil. 1984, 35, 203-228. [CrossRef]

28. Pereira, P.; Lopes, C.; Araújo, O.; Canário, J.; Almeida, A.; Pacheco, M. Fish eyes and brain as primary targets for mercury accumulation-A new insight on environmental risk assessment. Sci. Total. Environ. 2014, 494, 290-298. [CrossRef]

(C) 2020 by the authors. Licensee MDPI, Basel, Switzerland. This article is an open access article distributed under the terms and conditions of the Creative Commons Attribution (CC BY) license (http://creativecommons.org/licenses/by/4.0/). 